\title{
PURIFICATION AND CHARACTERIZATION OF BACTERIOCIN FROM Lactobacillus acidophilus HT1 AND ITS APPLICATION IN A CREAM FORMULA FOR THE TREATMENT OF SOME SKIN PATHOGES

\author{
Hiba T. Rasheed, \\ Researcher
} \\ Mouruj A. Alaubydi \\ Prof.
}

Dept Biotech, Coll Sci , University of Baghdad, Baghdad, Iraq

hibataqi211986@gmail.com khalidluti@yahoo.com mourujrabea@gmail.com

\section{ABSTRACT}

This study was aimed to purified and characterized the bacteriocin produced from Lactobacillus acidophilus HT1, in order to use it in a skin pharmaceutical formula. The optimal conditions for bacteriocin production was investigated and results showed that modified nutrient broth was the best medium with glucose $(30 \mathrm{gm} / \mathrm{L})$ and yeast extract $(7 \mathrm{gm} / \mathrm{L})$ with peptone $(7 \mathrm{gm} / \mathrm{L})$ were the optimum carbon and nitrogen sources. In addition, $2 \%$ inoculum size, $37 \mathrm{C} \circ$ and $\mathrm{pH} 6.4$ were the optimal conditions to obtain maximum bacteriocin of $640 \mathrm{AU} / \mathrm{ml}$ after $24 \mathrm{hrs}$. The bacteriocin was purified using $70 \%$ ammonium salt saturation and gel filtration with sephadex G50 that resulted $20 \%$ yield and $2560 \mathrm{AU} / \mathrm{ml}$ of activity, then the partial purified bacteriocin was characterized and found the bacteriocin was protein in nature and kept its activity after $10 \mathrm{~min}$ at 20,30 and $40 \circ \mathrm{C}$, however $50 \%$ of the activity was lost at $50 \mathrm{C}^{\circ}$. Moreover, it showed stability at $\mathrm{pH} 6$ and 7 for $30 \mathrm{~min}$ whereas; no activity was observed at pH 4 and 9. In addition, results showed that bacteriocin has a bactericidal effect rather than bacteriostatic. A cream formula contained the bacteriocin was prepared which already examined in vitro and in vivo. The effectiveness of the formula was confirmed using Klebsiella sp., Staphylococcus aureus and Pseudomonas aeruginosa as indicator strains. Results established that treatment at the onset time was more effective and the time of healing was decreased.

Key words: skin disease, antibacterial, probiotics.

رشيد وآخرون

مجلة العوم الزراعية العراقية -1393-1381:51:2020 م1:50

تنقية وتوصيف البكتريوسين المنتج من Lactobacillus acidophilus HT1 واستخذامة ضمن تركيبة الكريم لعلاج

$$
\begin{aligned}
& \text { بعض ممرضات الجلا } \\
& \text { هبة تقي رشيد } \\
& \text { قسم القتيات الاحيائية-كلية العلوم -جامعة بغداد }
\end{aligned}
$$

المستخلص

هدفت هذه الاراسة الى تنقية وتوصيف البكتريوسين المنتج من بكتريا Lactobacillus acidophilus HT1 واستخدامه ضمن تركيبة لعلاج جروح الجلد بالممرضات الجلاية, وقد حددت الظروف المثلى البكتريوسين المنتج, حيث كان الوسط المغذي المحور السائل افضل الفيل

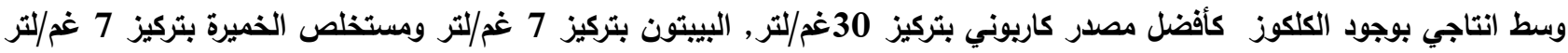

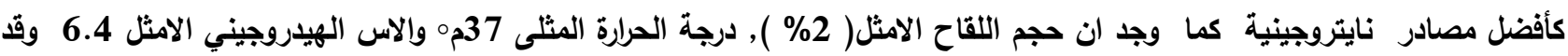

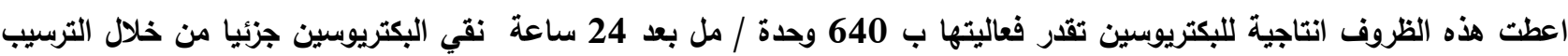

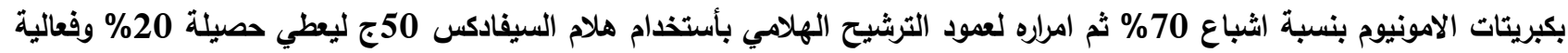

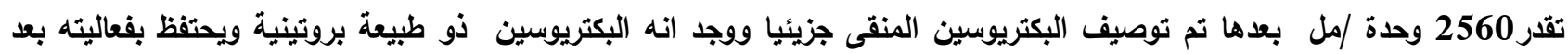

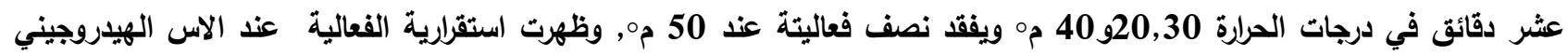

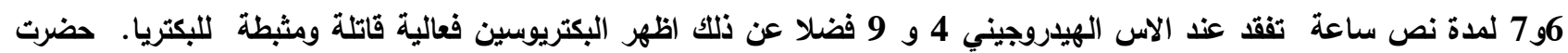

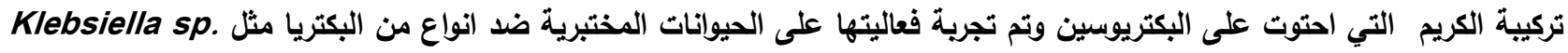
Staphylococcus aureus , المتسبية بالبكتريا اعلاه وتقليل وقت الثفاء. 


\section{INTRODUCTION}

Among the lactic acid bacteria, Lactobacilli (the species of the genus Lactobacillus) are the most commonly intestinal microbiota of vertebrates, including humans and involve themselves in fermentation of various foods, thereby improving the food quality and the health (10). Such microorganisms are generally recognized as safe (GRAS) and can be used as probiotics $(10,15)$. The antibacterial activity of probiotic Lactobacilli $s p$. appears to act through multifunctional ways, particularly by secreting antimicrobial substances such as bacteriocins and counteracting the spread within the colonized body or competing for nutrients and binding sites $(9,16)$. Bacteriocins are natural antimicrobial peptides produced by bacteria and can inhibit or kill bacterial strains mainly related to the producing bacteria $(1,19)$. Bacteriocins are considered as one of the bacterial weapons due to their specific characteristics with large diversity of function, structure and stability to heat. Many recent studies have identified and purified bacteriocins for different applications ranging from maintaining human health to food technology such as extending food preservation time, cancer therapy and treat pathogen disease (19). The skin and outer tissues are in direct contact with the environment and as a result microbes have easy enter to colonize these areas of the body. Therefore, our skin is populated by billions of numerous bacteria. Naturally, there are many microorganisms associated with skin infections (atopic dermatitis (AD), eczema, acne and burns contaminated) like Propionibacterium acnes, Staphylococcus aureus, Staphylococcus epidermidis, Pseudomonas aeruginosa, Corynebacterium (13). Experimental studies have shown that probiotics can exert specific influences in the dermatology via helping to treat skin conditions including bacterial infections, psoriasis, dermatitis, and the external signs of aging, acne, rosacea and yeast (7) . The action of probiotics is mainly based on producing antimicrobial compounds in particular, bacteriocins which can exert their health effects to the skin indirectly through dietary supplementary formulations or directly through cutaneous formulations (7). This study was focused on producing a bacteriocin from local isolate of Lactobacillus acidophilus with an activity against some common skin pathogens in order to introduce it in a pharmaceutical skin formula. The study involved testing the affectivity of the formula in vivo and in vitro.

\section{MATERIALS AND METHODS Microorganism}

A local isolate of Lactobacillus acidophilus HT1 was used throughout this work. This isolate was obtained from dairy products and human mouth samples and already identified through some biochemical tests and cultural characteristics as described by Bergey's manual and via molecular detection using $16 \mathrm{~S}$ ribosomal RNA gene (data not shown). Through preliminary tests, this isolate showed an ability to produce an active bacteriocin against several bacteria and hence was chosen to be used in this study. The maintenance of $L$. acidophilus HT1 was in MRS medium and incubated at $37^{\circ} \mathrm{C}$ for $48 \mathrm{hrs}$ in microaerophilic conditions.

Optimization of culture conditions Several optimization experiments were performed in order to determine the medium and culture conditions that support the maximal production of bacteriocin. The experiments involved testing different media including: Modified MRS broth (8) Modified Nutrient broth (NB), MRS broth, Low molecular weight liquid medium (LMWLM), Tyrptone Glucose Yeast (TGY) (23), Tryptone soya broth, Nutrient broth and MRS broth (21). In addition, the best and concentration of carbon and nitrogen sources, inoculum size, temperature, $\mathrm{pH}$ and incubation time were investigated. Basically, modified nutrient medium contain peptone and yeast extract which were subjected to optimization strategy in order to choose one nitrogen source that support both growth and bacteriocin production by L. acidophilus HT1. The procedure was based mainly on the removal experiment optimization approach as follow: first, each nitrogen source was investigated separately at $7 \mathrm{~g} / \mathrm{L}$ then half and equally amounts for the two-nitrogen sources amount as shown in Table 1. In all experiments, several $250 \mathrm{ml}$ Erlenmeyer flasks each 
contained $100 \mathrm{ml}$ of the best medium were prepared. After autoclaving, the flasks were inoculated with $2 \mathrm{ml}\left(2 \times 10^{8}\right)$ of $L$. acidophilus HT1 inoculum and incubated at 37 ${ }^{\circ} \mathrm{C}$ for $24 \mathrm{hrs}$ (Memmert-Germany incubator) then the samples were taken from each flask for the determination of bacteriocin activity and bacterial biomass which was measured as the dry weight of cell material (2) .

Table 1. Optimization of nitrogen source in the modified nutrient medium by the removal experiment optimization approach

\begin{tabular}{|ccc|}
\hline $\begin{array}{c}\text { Medium } \\
\text { composition }\end{array}$ & $\begin{array}{c}\text { Yeast extract } \\
(\mathrm{g} / \mathrm{l})\end{array}$ & $\begin{array}{c}\text { Peptone } \\
(\mathrm{g} / \mathrm{l})\end{array}$ \\
\hline Control & 2 & 5 \\
Medium 1 & 7 & 0 \\
Medium 2 & 0 & 7 \\
Medium 3 & 3.5 & 3.5 \\
Medium 4 & 2.0 & 2.0 \\
Medium 5 & 1.75 & 1.75 \\
Medium 6 & 7 & 7 \\
Medium 7 & 2.5 & 4.5 \\
Medium 8 & 4.5 & 2.5 \\
Medium 9 & 10 & 10 \\
\hline
\end{tabular}

Determination of bacteriocin activity Well diffusion assay was used to evaluate the production of bacteriocin of isolates as follows: An Amount of $20 \mathrm{ml}$ of MRS broth was inoculated with $2 \%$ of an overnight culture of each isolate contained approximately $10^{8}$ cells $/ \mathrm{ml}$. Then, media were incubated for $24 \mathrm{hrs}$ at $37^{\circ} \mathrm{C}$. After incubation, the culture broth was centrifuged at $10000 \mathrm{rpm}$ for $15 \mathrm{~min}$ and the cell-free supernatant (CFS) was collected and filtered with $0.22 \mu \mathrm{mMillipore}$ filter paper under sterile conditions, Several drops of $1 \mathrm{~N} \mathrm{NaOH}$ were added until reach $\mathrm{pH}$ for neutralize the effect of organic acid and $10 \mu$ catalase solution was added to avoid the $\mathrm{H}_{2} \mathrm{O}_{2}$ activity. Bacteriocin activity was detected using the dilution assay: a twofold dilution series of CFS of each isolate was prepared and bacteriocin activity was determined in each dilution against Pseudomonas aeruginosa using agar well diffusion assay (2). The highest dilution producing an inhibition zone (DF) reflected the strength of bacteriocin activity. The bacteriocin activity which is known as arbitrary unites (AU) was determined using the following equation (2):

$$
\mathrm{AU} / \mathrm{ml}=\frac{1}{D F} \mathrm{X} \frac{1000}{\text { volums spotted in } \mu l}
$$

\section{Purification of bacteriocin}

Bacteriocin was first precipitated by ammonium sulphate at different saturation levels $(20,40,50,60,70,80,90) \%$ at $4^{\circ} \mathrm{C}$. The precipitate was separated by centrifugation for $30 \mathrm{~min}$ at $10000 \mathrm{rpm}$. Then the precipitates were dissolved in an appropriate volume of phosphate buffer $(0.1 \mathrm{M}, \mathrm{pH} 7.2)$ and dialyzed in 0.5 liter of phosphate buffer overnight at $4^{\circ} \mathrm{C}$ using dialysis membrane tubes $(1 \mathrm{kDa}$ MW cutoff). The buffer was replaced four times. The antibacterial activity of the dialyzed protein was determined by agar well diffusion assay using $P$. aeruginosa as an indicator strain (6). The resulting bacteriocin was loaded on a column $(3 \times 20 \mathrm{~cm})$ of sephadex G-50 gel filtration. Elution was performed with phosphate buffer $(0.1 \mathrm{M}, \mathrm{pH} 7.2)$ with a flow rate of $36 \mathrm{ml} /$ hour and fractions of $3 \mathrm{ml}$. The absorption was measured at $280 \mathrm{~nm}$. The fractions were tested for antibacterial activity against $P$. aeruginosa as an indicator strain by well agar diffusion assay. Fractions showed antimicrobial activity were mixed in one tube and protein concentration with Bradford method (14) and bacteriocin activity were determined (12).

\section{Characterization of bacteriocin}

The sensitivity of the bacteriocin produced from Lactobacillus acidophilus HT1 to the proteolytic enzyme trypsin was tested. Trypsin was dissolved in $0.1 \mathrm{M}$ potassium phosphate buffer ( $\mathrm{pH}$ 7.2) in a test tube contained the bacteriocin solution with an activity of 2560 $\mathrm{AU} / \mathrm{ml}$ for a final concentration of $1 \mathrm{mg}$ trypsin $/ \mathrm{ml}$. The control contained the bacteriocin solution with an activity of 2560 AU/ml without trypsin. Tubes were incubated at $37^{\circ} \mathrm{C}$ and bacteriocin activity was measured at zero time and after 30 and 90 mins using the well diffusion assay method $(5,22)$. Furthermore, in order to test the thermo stability of bacteriocin, samples were exposed to different temperatures $(30,40,50,60,70$, $80,90){ }^{\circ} \mathrm{C}$ for 10 mins followed by cooling on an ice-bath. The residual activity was then determined by agar-well diffusion technique against indicator strain. In addition, bacteriocin was treated with either $0.1 \mathrm{~N} \mathrm{HCl}$ or $0.1 \mathrm{~N} \mathrm{NaOH}$ to achieve the desired $\mathrm{pH}$ values between 4 and 9 . The $\mathrm{pH}$ adjusted crude extracts were incubated for 30 mins. 
After incubation, aliquots were neutralized and activity was measured by agar-well diffusion technique against indicator strain.

\section{Mode of bacteriocin action}

The mode of action of the bacteriocin against $P$. aeruginosa was investigated. A volume of $0.5 \mathrm{ml}$ of the partial purified bacteriocin with total activity of $2560 \mathrm{AU} / \mathrm{ml}$ was added to 10 $\mathrm{ml}$ of an overnight culture of $P$. aeruginosa grown in nutrient broth at $37^{\circ} \mathrm{C}$ (OD $600 \mathrm{~nm}$ $=0.6$ of $P$. aeruginosa). Control culture was prepared without adding bacteriocin. Changes in the turbidity at $600 \mathrm{~nm}$ and viable cells count $(\mathrm{cfu} / \mathrm{ml})$ were measured at zero time and after 10, 30, 60, and $120 \mathrm{~min}$ of incubation. Viable cells count was determined on nutrient agar plates (20).

Preparation of pharmaceutical formula including bacteriocin

A cream contained the partial purified bacteriocin was prepared as follow modified (17): An amount of 0.1 gm of methyl paraben was dissolved in $1 \mathrm{ml}$ of ethanol $(70 \%)$. Then $49 \mathrm{ml}$ of olive oil was gradually added with continues mixing. $5 \mathrm{ml}$ of partially purified bacteriocin with an activity of $2560 \mathrm{AU} / \mathrm{ml}$ was added with mixing until homogenization. Next, an amount of $50 \mathrm{gm}$ of white petroleum vaseline was added gradually with continuous mixing to homogenization.

\section{Preparation of bacterial indicators}

Three multidrug resistant bacterial isolates: Staphylococcus aureus, Klebsiella sp, Pseudomonas aeruginosa were used as indicators in in vitro and in vivo experiments. These indicators were activated in brain heart infusion broth and incubated at $37^{\circ} \mathrm{C}$ for $24 \mathrm{hrs}$. The number of cells was adjusted according to McFarland tube (0.5) which is equal to $1.5 \times 10^{8} \mathrm{cell} / \mathrm{ml}$ at $600 \mathrm{~nm}$.

In vitro evaluation of formula including bacteriocin

The antibacterial activity within the formula containing bacteriocin as active material was investigated by well diffusion method (18).

In vivo evaluation of formula including bacteriocin

Number of 12 local white rabbits were divided into 3 groups each group included 3 animals as treated animals and the fourth one was considered as a control. Each group was specified for one indicator bacteria. After adaptation period ( 3 days), rabbits' shoulder and thigh regions were shaved and injured using a scalpel. Then, each rabbit group was infected with one of bacterial indicator and grouped as (1,2 and 3) for Pseudomonas aeruginosa, Staphylococcus aureus and Klebsiella respectively. Each group of experiment was treated as follow: One of rabbit are treated at the onset time after infection (treatment directly after infection), this group was considered as prophylactic group. Another lab. animal was treated with final formula containing active material (bacteriocin) after few hours from infection time and considered as treatment group. The last one was treated after inflammation appearance by using the formula components only without active material (bacteriocin). The experiment time was based on the time of complete healing and this new formula was applied twice daily.

\section{RESULTS AND DISCUSSION}

The increasing developments of resistance to antibiotics have heightened the need for new strategies to compete pathogens. Researchers have shown an increased interest in bacteriocins as a possible alternative to antibiotics. As mentioned earlier, our target in this study was to obtain an active bacteriocin in order to use it in a skin pharmaceutical formula. In preliminary tests, Lactobacillus acidophilus $H T 1$ showed an ability to produce an effective bacteriocin against some common skin pathogens in particular, Pseudomonas aeruginosa, Klebsiella $s p$ and Staphylococcus aureus (data not shown). Therefore, this isolate was selected to be used to produce the bacteriocin that can be applied in a cream formula.The optimized cultural parameters that required for elevating bacteriocin production from Lactobacillus acidophilus HTl such as media(carbon and nitrogen sources), inoculum size, $\mathrm{pH}$, temperature, and the incubation time were investigated. Different media were used in order to select the best one that can support the maximum production of bacteriocin. Based on the results presented in Figure 1A, the maximum production of bacteriocin was found when $L$. acidophilus HT1was grown in the Modified NB in which bacteriocin activity and biomass were $640 \mathrm{AU} / \mathrm{ml}$ and $12.6 \mathrm{mg} / \mathrm{ml}$ respectively. 
Then, the next step was to manipulate with media contents such as carbon source and nitrogen source. For this purpose, different carbon sources were used. Based on the results presented in Figure $1 \mathrm{~B}$, the highest bacteriocin activity of $640 \mathrm{AU} / \mathrm{mL}$ was achieved when glucose was used as carbon source in which biomass was $12.6 \mathrm{mg} / \mathrm{ml}$. in addition, results showed that glucose concentrations 20,25 , and $30 \mathrm{gm} / \mathrm{L}$ gave the highest bacteriocin production with 640 $\mathrm{AU} / \mathrm{ml}$, however the production of biomass was varied ranging from 12.6 to $5.8 \mathrm{mg} / \mathrm{ml}$ (Figure 1D ). Accordingly, the product yield factor on biomass $Y_{P / x}^{\prime}$, which relates to the amount of bacteriocin formed to the amount of biomass produced, was $0.05,0.07,0.11$ in the cultures contained 20,25 and $30 \mathrm{~g} / \mathrm{L}$ glucose respectively. Therefore, the $30 \mathrm{~g} / \mathrm{L}$ was chosen as the best concentration of glucose to be used in further experiments. Basically, modified nutrient medium contain peptone and yeast extract which were subjected to an optimization strategy in order to choose one source that support both growth and bacteriocin production by L. acidophilus HT1. The procedure was based mainly on the removal experiment optimization approach as follow: first, each nitrogen source was investigated separately at $7 \mathrm{~g} / \mathrm{L}$ then half and equally for the two-nitrogen sources amount. The presence of both nitrogen sources (yeast extract and peptone) was necessary to supported bacteriocin production. However, maximum bacteriocin production of 640 $\mathrm{AU} / \mathrm{ml}$ was observed in control medium. The results showed that bacteriocin production was suppressed in media 1 and 2 As shown in Figure 1C, the best inoculums size for the maximum bacteriocin production was $2 \%$ as shown in Figure 2A. Moreover, results showed that the maximum production of bacteriocin was obtained at $37^{\circ} \mathrm{C}$ and $\mathrm{pH} 6$ (Figure $2 \mathrm{~B}$, 2C). Furthermore, maximum production of bacteriocin was observed after $24 \mathrm{hrs}$ of incubation with an activity of $640 \mathrm{AU} / \mathrm{ml}$.
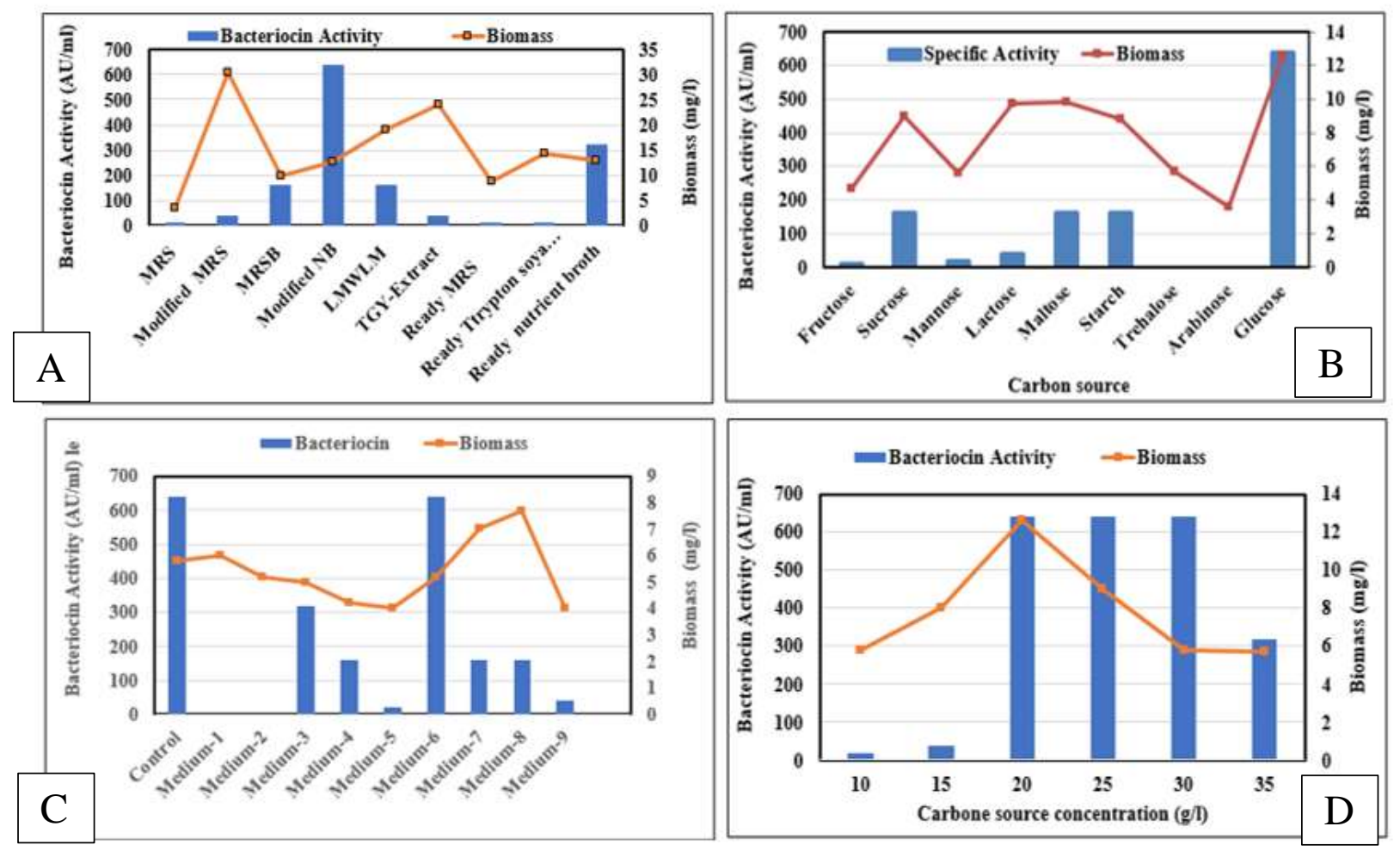

Figure 1. Optimization of culture conditions for bacteriocin production by $L$. acidophilus HT1: best medium (A), carbon source (B), nitrogen source (C), carbon source concentration

(D) 

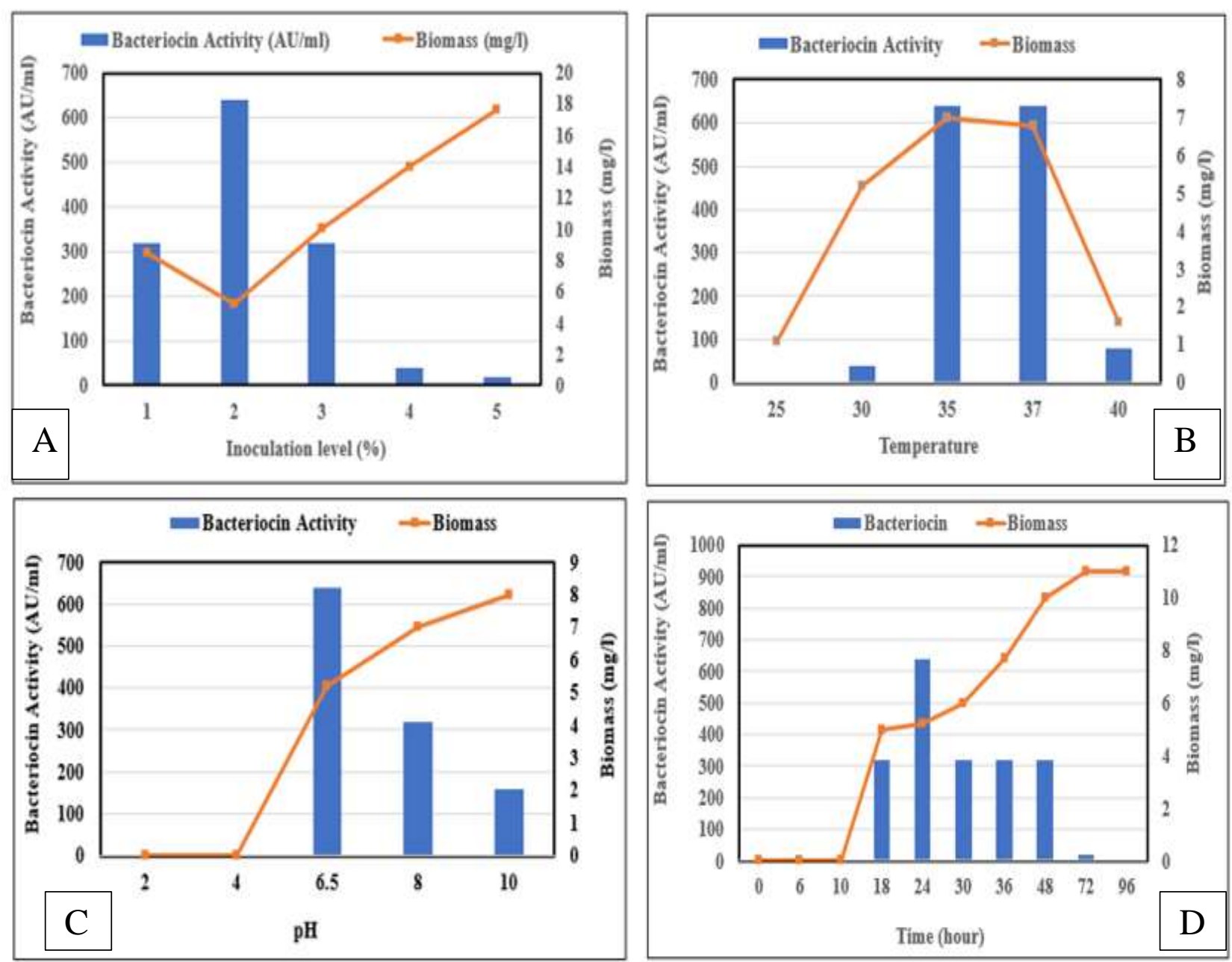

Figure 2. Optimized cultural parameters for elevating bacteriocin production by $L$. acidophilus

Next, bacteriocin produced by L. acidophilus HT was precipitated from the culture supernatant by saturation with different concentrations of ammonium sulfate ranging from 20 to $90 \%$, followed by dialysis to remove salts and impurities. Based on the results maximum bacteriocin precipitation was obtained at $70 \%$ saturation level. The bacteriocin activity was $1280 \mathrm{AU} / \mathrm{ml}$ with specific activity of $4266.6 \mathrm{AU} / \mathrm{mg}$. The precipitated bacteriocin was then loaded in sephadex G-50. The antimicrobial assay was performed for each fraction using $P$. aeruginosa as indicator strain by agar well assay., two separated peaks were obtained in the separation profile. The bacteriocin activity was found in the fractions 31 to 36 (Figure $3)$. The active fractions were collected and concentrated by sucrose to obtain the $5 \mathrm{ml}$, the activity as well as specific activity of the partial purified bacteriocin was calculated as demonstrated in the purification (Table 2). 


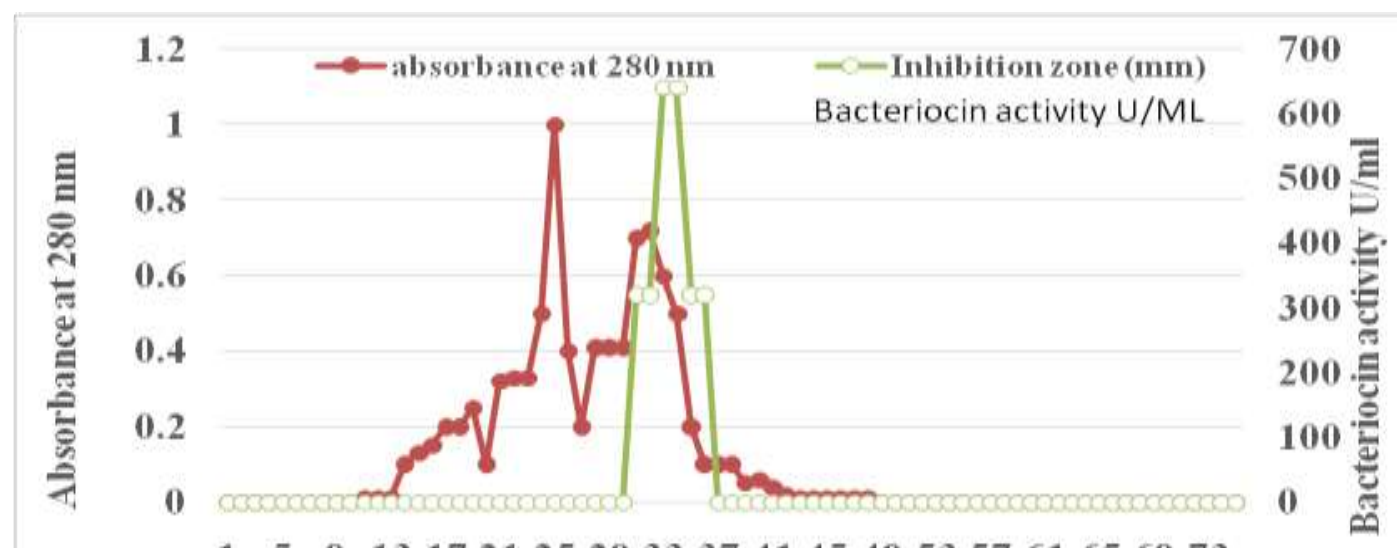

15913172125293337414549535761656973

Fraction No.

Figure 3. Purification of bacteriocin produced by $L$. acidophilus HT1 by Sephadex G-50 column $(3 \times 20 \mathrm{~cm})$. Column was equilibrated and eluted with sodium phosphate buffer, pH 7 at a flow rate of $0.6 \mathrm{ml} / \mathrm{min}$

Table 2. Summary of purification of bacteriocin from crude culture filtrate of L. acidophilus HT1

\begin{tabular}{|c|c|c|c|c|c|c|c|}
\hline Purification steps & $\begin{array}{c}\text { Volume } \\
\mathrm{ml}\end{array}$ & $\begin{array}{c}\text { Activity } \\
\text { (U/ml) }\end{array}$ & $\begin{array}{c}\text { Protein } \\
\text { concentration } \\
\mathbf{m g} / \mathbf{m l}\end{array}$ & $\begin{array}{c}\text { Total } \\
\text { activity } \\
\text { U }\end{array}$ & $\begin{array}{l}\text { Specific } \\
\text { activity } \\
\mathrm{U} / \mathrm{mg}\end{array}$ & $\begin{array}{c}\text { Yield } \\
\%\end{array}$ & $\begin{array}{c}\text { Fold } \\
\text { purification }\end{array}$ \\
\hline Crud extract & 100 & 640 & 0.5 & 64000 & 1280 & 100 & 1 \\
\hline $\begin{array}{c}\text { Ammonium salt } \\
\text { precipitation 70\% }\end{array}$ & 15 & 1280 & 0.3 & 19200 & 4266.6 & 30 & 3.33 \\
\hline $\begin{array}{l}\text { Gel filtration } \\
\text { sephadex G } 50 \text { after } \\
\text { concentrated by } \\
\text { sucrose }\end{array}$ & 5 & 2560 & 0.2 & 12800 & 12800 & 20 & 10 \\
\hline
\end{tabular}

Next, the main characters of the purified bacteriocin were investigated. As can be seen in (Figure 4A), bacteriocin activity was reduced when treated with trypsin. The results showed that bacteriocin activity was decreased to $50 \%(1280 \mathrm{AU} / \mathrm{ml})$ after $30 \mathrm{~min}$ of incubation and it was completely lost after 90 mins confirming the protein nature of bacteriocin. Thermal stability of bacteriocin is an important criterion that can help to determine whether the bacteriocin is belong to the class of heat-labile or heat -stable protein (11). As can be seen in Figure 4B, the activity of bacteriocin was kept stable after $10 \mathrm{~min}$ at $20,30,40 \circ \mathrm{C}$ as no effect was observed on its antimicrobial activity. However, approximately $50 \%$ of the bacteriocin activity was lost after exposure to $50^{\circ} \mathrm{C}$ for $10 \mathrm{~min}$ and further decreased to $160 \mathrm{AU} / \mathrm{ml}$ at $60{ }^{\circ} \mathrm{C}$ and decreased gradually at $70^{\circ} \mathrm{C}$ and to reach to 20 $\mathrm{AU} / \mathrm{ml}$ at $80 \circ \mathrm{C}$. From these results, it can be concluded that the bacteriocin is heat -labile. In addition, results revealed that bacteriocin activity showed stability at $\mathrm{pH} 6$ and 7 in which the bacteriocin kept its activity of 2560
AU/ml for $30 \mathrm{~min}$. However, bacteriocin activity was decreased to approximately $50 \%$ (1280 AU/ml) at $\mathrm{pH} 8$, whereas, no activity was observed at $\mathrm{pH} 4$ and 9 as shown in Figure 5. On the other hand, the mode of action of the partially purified bacteriocin was studied using $P$. aeruginosa as an indicator strain. According to results, a rapid decline in the number of viable cells Figure (6 A) and optical density Figure $(6 \mathrm{~B})$ in the tube which contained $P$. aeruginosa culture with bacteriocin was observed. The number of cells in this tube was decreased to approximately zero within $2 \mathrm{hrs}$. Whereas, no effect was seen on the growth of $P$. aeruginosa in the control tube. These results suggest that the bacteriocin has a bactericidal effect rather than bacteriostatic. Bacteriocins may possess a bactericidal or bacteriostatic mode of action on sensitive cells, this distinction being greatly influenced by several factors such as bacteriocin dose and degree of purification, physiological state of the indicator cells and experimental conditions (3) . The next step was applied the bacteriocin in a suitable pharmaceutical formula. 
Bacteriocins are antibacterial proteins produced by bacteria that kill or inhibit the growth of other bacteria (4). In this study, because the bacteriocin produced from $L$. acidophilus $H T 1$ is protein and soluble in water, therefore the formula must contain materials maintain this chemical structure with its activity. Thus, bacteriocin was prepared as a cream and examined in vitro and in vivo. In in vitro experiment, the antibacterial activity of cream formula containing bacteriocin was investigated against $P$. aeruginosa using well diffusion assay. According to results, a significant inhibition zones were observed around wells contained the bacteriocincontaining cream. Inhibition of $P$. aeruginosa growth was certainly demonstrated the efficiency of the formula through several points included; activity of bacteriocin and its releasing throughout the formula to the external environment (tested media). The results confirmed the absence of trapping or interaction among bacteriocin and any component of the formula that may counteract bacteriocin ability to inhibit tested bacteria.In addition, the bacteriocin-containing formula was tested in vivo with ultimate aim of application for the improvement of antimicrobial effect for the removal of pathogenic bacteria. As can be seen in Figures 7,8 and 10 , the infected wounds were varied during the period of experiment from severe inflammation that may be some- time became purulent especially for $S$. aureus group to mild inflammation and healing. In addition, the results showed that, all usable pathogenic bacteria were susceptible to the bacteriocin in particular, Klebsiella sp. which was more susceptible than other indicator bacteria. Furthermore, all groups of experiment exhibited a significant prophylactic effect (treatment was begun at the onset time of infection) of bacteriocin against pathogenic bacteria. Moreover, treatment at the onset time was more effective and consequently the time of complete healing was decreased. In addition, the formula showed an improvement in the efficiency based on its capability to support bacteriocin which acts as active ingredient to reach different parts of skin and prevent the dominant of severe infection.
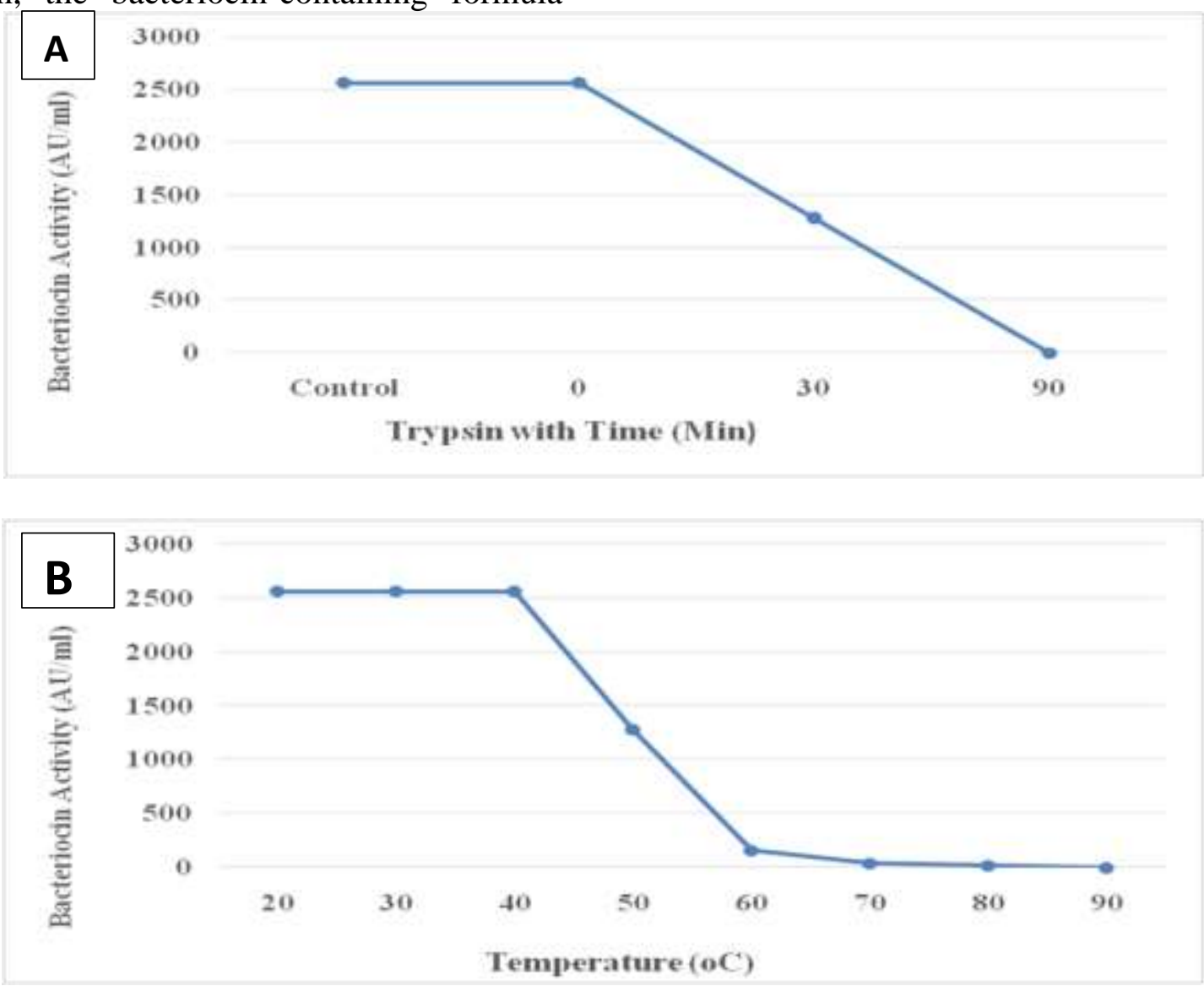

Figure 4 . Effect if trypsin (A) and temperature (B) on bacteriocin produced by Lactobacillus acidophilus HT 1 


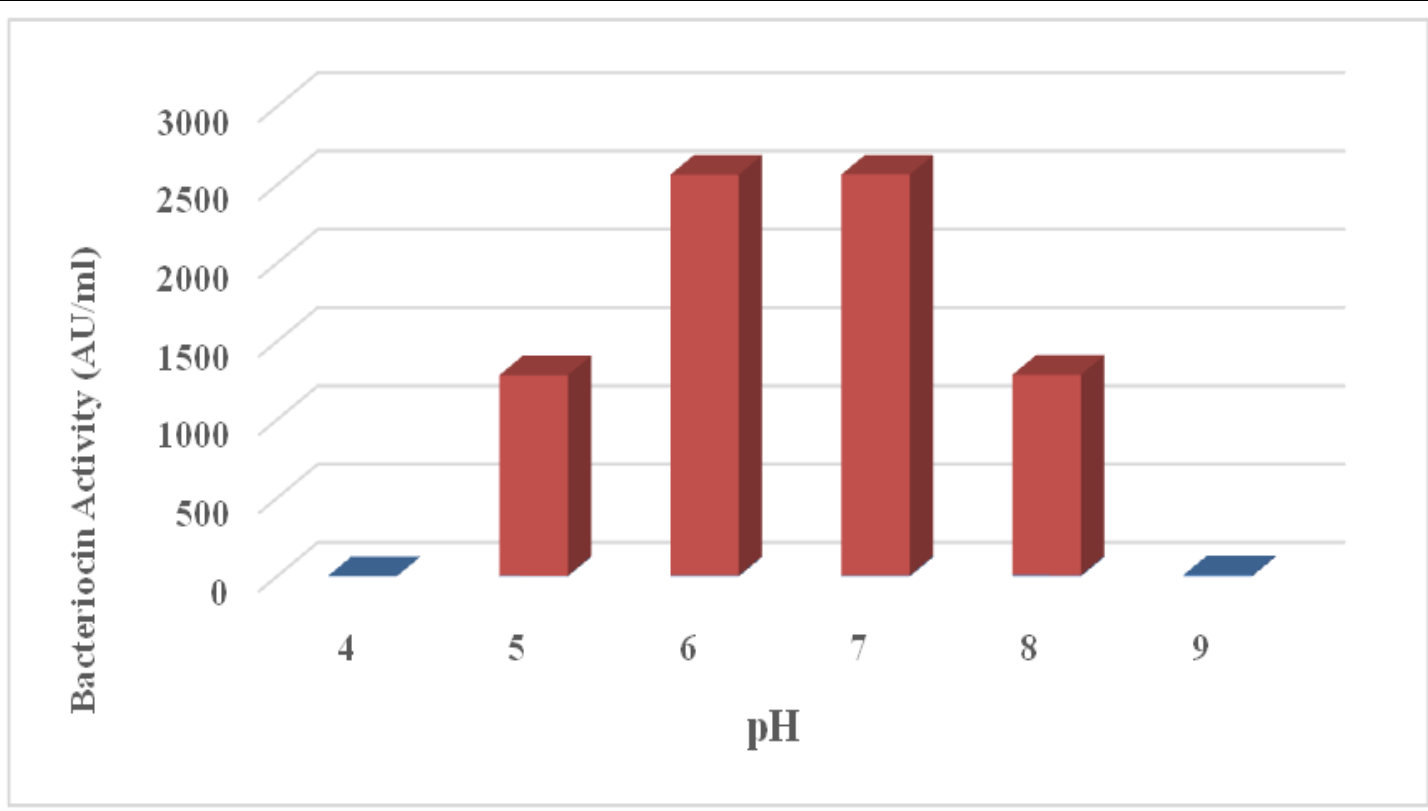

Figure 5 - pH stability of bacteriocin from Lactobacillus acidophilus HT 1 after exposed to different $\mathrm{pH}$ for $30 \mathrm{~min}$

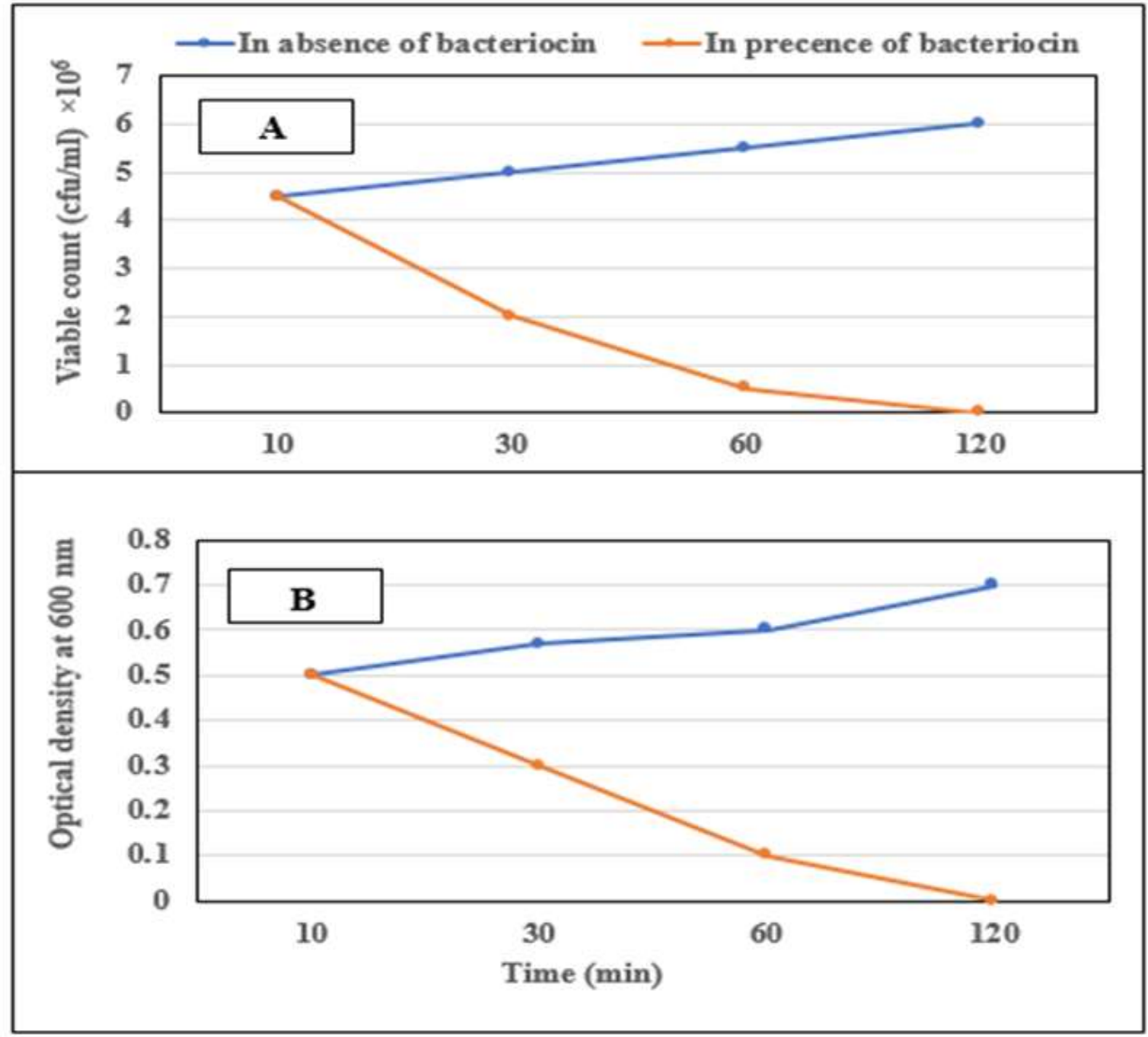

Figure 6. Mode of action of partially purified bacteriocin produced by L. acidophilus HT1 against $P$. aeruginosa. Viable cell counts $(\mathrm{CFU} / \mathrm{ml})$ in the absence or presence of partial purified bacteriocin (A). Optical density at $600 \mathrm{~nm}$ in the absence or presence of partial purified bacteriocin (B). 


\begin{tabular}{|c|c|c|c|}
\hline Type of formula & 3 days & 5 days & 7 days \\
\hline $\begin{array}{l}\text { Complete formula } \\
\text { with bacteriocin } \\
\text { against } S \text {. aureus }\end{array}$ & & & \\
\hline $\begin{array}{l}\text { Complete formula } \\
\text { components only }\end{array}$ & & & \\
\hline $\begin{array}{l}\text { Treatment with } \\
\text { complete formula } \\
\text { at the onset of } \\
\text { infection }\end{array}$ & & & \\
\hline Control & & & \\
\hline
\end{tabular}

Figure 7. In vivo experiment for applying bacteriocin produced by L. acidophilus HT1 formula to treat a group of rabbits infected with Staphylococcus aureus. 


\begin{tabular}{|l|l|l|l|}
\hline Type of formula & 3 days & & \\
\hline $\begin{array}{l}\text { Complete formula } \\
\text { with bacteriocin } \\
\text { against } \\
\text { Klebsiella.spp }\end{array}$ & & & \\
\hline
\end{tabular}

Figure 8 . In vivo experiment for applying bacteriocin produced by L. acidophilus HT1 formula to treat a group of rabbits infected with Klebsiella sp. 


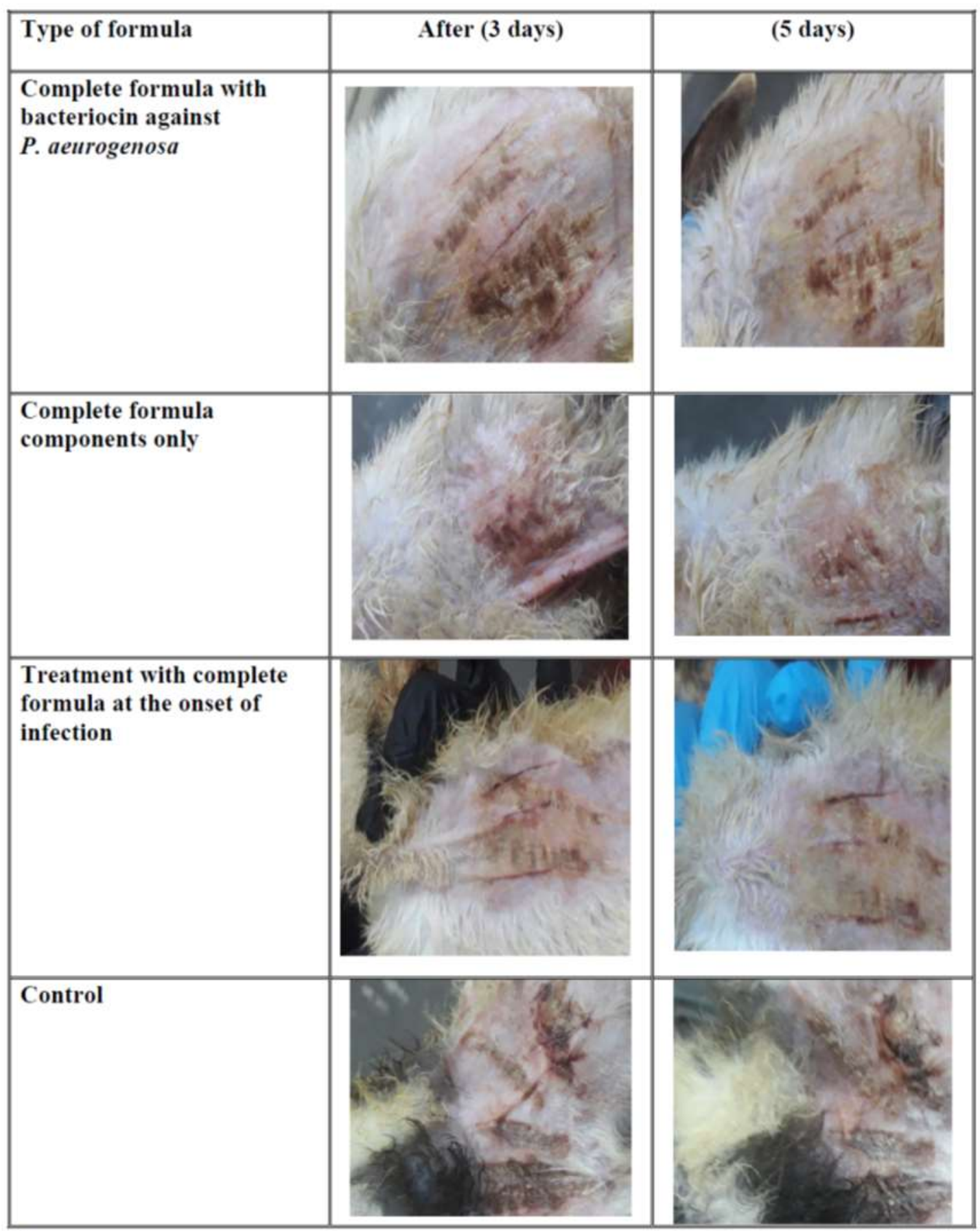

Figure 9. In vivo experiment for applying bacteriocin produced by L. acidophilus HT1 formula to treat a group of rabbits infected with $P$. aeuroginosa

\section{REFERENCES}

1. AL-Gbouri and A. G. Hamzah, 2018. Evalution pf phyllanthus emblica extracts as antibacterial and antibiofilm against biofilm formation bacteria. Iraq J Agri Sci. 49(1) 2240

2. Abd, F.N. and K. Luti, 2017. An Exploitation of Interspecies Interaction for Promoting Bacteriocin Production by Local Isolate of Bacillus.sp M.Sc. Thesis. Department of Biotechnology, College of
Science, University of Baghdad. 60:( 3) 494508

3. Cintas, L. M.; C. Herranz ; P. E. Hernández; M. P. Casaus and L. F. Nes, 2001 . Review: Bacteriocins of lactic acid bacteria. Food Sci. Tech. Int; 7: 281-305

4. Cleeveland, J.; T. J. Montville; I.F. Nes and M.L. Chikindas, 2001. Bacteriocins : Safe, natural antimicrobial for food preservation International J Food Microbiol; 71: $1-20$ 
5. Chin, H. S.; J. S. Shim; J. M, Kim; R. Yang and S. S. Yoon, 2001. Detection and antibacterial activity of a bacteriocin produced by Lactobacillus plantarum. Food Sci. and Biotechnol., 10(5): 461-467.

6. Charles, P.; V. Devanathan; P. Anbu; M. N. Ponnuswamy ; P. T.Kalaichelvan and B. K. Hur, 2008. Purification, characterization and crystallization of an extracellular alkaline protease from Aspergillus nidulans HA-10. J. of bas. Microbial., 48(5): 347-352

7. Cinque, B.; C Torre; E. Melchiorre; G. Marchesani; G. Zoccali; G.;Palumbo, P.; Marzio, L. D.; Masci, A.; Mosca, L.; Mastromarino, P.; Giuliani, M. and M. G. Cifone,. 2011. Use of probiotics for dermal applications. In: Probiotics, Microbiology Monographs. Liong, M.-T., Ed., Springer Verlag, Berlin, Heidelberg. 10(9): 460-468.

8. Dyaee, N. and K. Luti, 2019. Classical and statistical optimization by response surface methodology for enhancing biomass and bacteriocin production by Lactobacillus Plantarum. Iraqi J of Sci, ; 60:( 3) 494-508

9. Eid, R ; J.E .Jakee ; A. Rashidy; H. Asfour; S. Omara ; M.M.Kandil; Z.Mahmood; J. Hahne and A.A. Seida 2016. Potential antimicrobial activities of probiotic Lactobacillus strains isolated from raw milk. Probiot. Health; 4: 138

10. Fuller, R. 1989 . Probiotic in man and animals: A review. J. Appl. Bacteriol; 66: 365-378

11. Heng, N.C.K.; P.A. Wescombe ; J.P. Burton; R.W. Jack and J.R. Tagg , 2007 . The diversity of bacteriocins in Gram-positive bacteria. In: Bacteriocins: Ecology and evolution. riley MA and Chavan M. Springer, Berlin; 7: 45-92

12. Hammami, I.; B. Jaouadi ; A. Ben Bacha ; A. Rebai ; S. Bejar ; X. Nesme and R. Ali, 2012. Bacillus subtilis bacteriocin Bac 14B with a broad inhibitory spectrum: purification, amino acid sequence analysis, and physicochemical characterization. Biotechnol. and Bio,Eng, 17: 41-49.

13. Harder, J.; J. Bartels; E. Christophers and JM. Schroder ,1997. A peptide antibiotic from human skin. Nature; 387:861
14. Kruger, N.J. 2002. The Bradford Method of Protein Quantification. In J.W. Walker (ed.). The Protein Protocols Handbook, $2^{\text {nd }}$ ed. Humana Press Inc.; Totowa, New Jercy. 9: 1521

15. Khaleel, M .M . and A. A. Thaer 2017. Using probiotic and inulin to prolong fermented dairy products shelef. Iraq J Agri Sci . 48 (2): 608-617

16. Mahdi, L. H. 2017. Immuomodulatory of Bifidobacterium breve and inhibatory effect of bifidobrevicin LHM on Streptococcus agalactiae and ITS $\beta$ - hemolysin. Iraq J Agri Sci. 48: (Special Issue): 651-671

17. Mishra, A.; S. Saklani ; L. Milella and P. Tiwari, 2014 . Formulation and evaluation of herbal antioxidant face cream of Nardostachys jatamansi collected from Indian Himalayan Region. Asian Pac J Trop Biomed; 4:679-82

18. Mayr-Harting, A.; A.J. Hedges and C.W. Berkeley, 1972. Methods for studying bacteriocins. Methods Microbiol; 7: 315-412

19. Shih-Chun, Y.; L. Chih-Hung; S. Calvin and F. Jia-You, 2014. Antibacterial activities of bacteriocins: application in foods and pharmaceuticals; $5:$ 241- 7

20. Sirtori, L. R.; A. D. Motta and A. Brandelli, 2008. Mode of action of antimicrobial peptide $\mathrm{P} 45$ on Listeria monocytogenes. Journal of Basic Microbiology, 48(5):393-400

21. Todorov S. D. and L. M. T. Dicks , 2004. Influence of Growth conditions on the production of a bacteriocin by Lactococcus lactis subp. lactis ST 34BR, a strain isolated from barley beer. Journal of Basic Microbiology; 44:305-316

22. Yamato, M.; K. Ozaki and F. Ota, 2003. Partial purification and characterization of the bacteriocin produced by Lactobacillus acidophilus YIT 0154. Microbiol. Resea.,158 (2):169-172

23. Zacharof M. P. and R. W. Lovittb, 2012. Bacteriocins Produced by Lactic Acid Bacteria, A Review Article, Bangkok, Thailand. April 7-8. 